\title{
Study on a family with Anderson-Fabry's disease and associated familial spastic paraplegia
}

\author{
A. M. PIERIDES, G. HOLTI, A. L. CROMBIE, D. F. ROBERTS, S. E. GARDINER, \\ A. COLLING, and J. ANDERSON

\begin{abstract}
From the Royal Victoria Infirmary, Newcastle upon Tyne; and M.R.C. Human Biochemical Genetics Unit, Galton Laboratory, University College, London
\end{abstract}

\begin{abstract}
Summary. A family in the north-east of England with Anderson-Fabry's disease is presented. Alpha-galactosidase activity in plasma and white cells was significantly reduced in three adult male members of the family. One of them had an abnormal chromosome karyotype pattern with an extra $\mathrm{Y}$ chromosome (47,XYY) and he was clinically less severely affected than his brothers. Coincidentally five other members of the family suffered from a form of familial spastic paraplegia.
\end{abstract}

Since the original description of the disorder by Anderson (1898) and Fabry (1898) the concept of this condition has gradually evolved from a purely dermatological curiosity to a generalized systemic disorder, shown by Scriba (1950) to be the result of an abnormality of lipid metabolism. Sweeley and Klionsky (1963) and Jensen (1966) established the disease specifically as a disorder of glycolipid metabolism and Brady et al (1967) identified it as an inborn error of metabolism caused by the absence of ceramide trihexosidase, an enzyme later shown to be a specific $\alpha$-galactosidase (Kint, 1970). Deficiency of this enzyme leads to intracellular accumulation throughout the body of ceramide trihexoside, and blood vessels are particularly affected; cardiovascular and renal disease are usually the terminal event in the fourth and fifth decades of life.

Wallace (1973) has recently reviewed this disease comprehensively. He emphasized that early diagnosis was necessary to allow timely genetic advice.

The purpose of this study is to describe an unusual, previously unreported, family with Anderson-Fabry's disease in the north-east of England in which one member had a $47, \mathrm{XYY}$ chromosome complement.

\section{Methods}

All members of the family with Anderson-Fabry's disease were clinically examined and had full ophthalmological assessment. Skin lesions were studied histo-

Received 10 December 1975. logically and bone marrow and rectal wall biopsies were done in the three living brothers with the disease. Full chromosome analysis by leucocyte culture using banding techniques was carried out on the three surviving affected brothers. Several lysosomal enzymes were assayed in the plasma and white cells of 3 living brothers using the appropriate 4-methylumbelliferyl substrate. The method is described in Table $I$.

\section{The family}

The family tree comprising 4 generations and 36 subjects is shown in Fig. 1. Four brothers in generation IV have been affected by Anderson-Fabry's disease. Good circumstantial evidence suggests that their mother (III.13 FM) had a mild form of the syndrome. Five other members of the family had signs and symptoms of familial spastic paraplegia. Members III.1, III.10, III.12, and III.13 died paraplegic. In these subjects weakness of the legs started after the second decade and progressed slowly but relentlessly. Ataxia was a prominent feature of III.13 FM and was also noted in the maternal grandmother (II.5 LP). The case histories of the members with Anderson-Fabry's disease are given below and IV.6, GM, a representative patient, is described in detail.

Case IV.6 (GM D/B 26. II. 1930). GM, the eldest brother, had an unremarkable development until the age of 5 when he began to complain bitterly of pains in his legs and feet. Later his arms and hands were also affected, particularly the knuckles. On occasions he would complain of a vague persisting pain in his mouth. Exercise, such as walking home from school could precipitate an attack of pain and the child often returned home crying. Hot weather was particularly unbearable. 
TABLE I

METHODS USED FOR ASSAY OF LYSOSOMAL ENZYMES

\begin{tabular}{|c|c|c|}
\hline Enzyme & Assay Mixture & $\begin{array}{l}\text { Duration of } \\
\text { Incubation } \\
\text { at } 37^{\circ} \mathrm{C}\end{array}$ \\
\hline $\begin{array}{l}\text { A: Plasma } \\
\alpha \text {-galactosidase }\end{array}$ & $\begin{array}{l}100 \mu \mathrm{l} \text { plasma }+200 \mu \mathrm{l} 0.1 \mathrm{M} \\
\text { citrate/phosphate } \mathrm{pH} 4.5 \\
\text { containing } 1 \mathrm{mg} / \mathrm{ml} 4- \\
\text { methylumbelliferyl-a-D- } \\
\text { galactopyranoside (Koch- } \\
\text { Light) }\end{array}$ & $\begin{array}{c}20 \text { and } 40 \\
\text { minutes }\end{array}$ \\
\hline $\begin{array}{l}\text { N-acetyl- } \beta-D- \\
\text { hexosaminidase }\end{array}$ & $\begin{array}{l}50 \mu \mathrm{l} \text { plasma (diluted } 1 \text { in } 5 \text { ) } \\
+100 \mu 10.05 \mathrm{M} \text { citrate } \\
\text { pH } 4.5 \text { containing } 0.5 \mathrm{mg} / \mathrm{ml} \\
4 \text {-methylumbelliferyl-2- } \\
\text { acetamide-2-deoxy- } \beta-\mathrm{D}- \\
\text { glucopyronoside (Koch- } \\
\text { Light) }\end{array}$ & 20 minutes \\
\hline$\alpha$-mannosidase & $\begin{array}{l}100 \mu \mathrm{l} \text { plasma }+200 \mu \mathrm{l} 0.1 \mathrm{M} \\
\text { citrate/phosphate } \mathrm{pH} 4.5 \\
\text { containing } 1 \mathrm{mg} / \mathrm{ml} 4- \\
\text { methylumbelliferyl-a-D- } \\
\text { mannopyranoside (Koch- } \\
\text { Light) }\end{array}$ & 20 minutes \\
\hline $\begin{array}{l}\text { B: White cells } \\
\alpha \text {-galactosidase }\end{array}$ & $\begin{array}{l}10 \mu \mathrm{l} \text { extract }+200 \mu \mathrm{l} 0.1 \mathrm{M} \\
\text { citrate/phosphate } p \mathrm{H} 4.5 \\
\text { containing } 1 \mathrm{mg} / \mathrm{ml} 4- \\
\text { methylumberlliferyl-a-D } \\
\text { galactopyranoside }\end{array}$ & $\begin{array}{r}10 \text { and } 20 \\
\text { minutes }\end{array}$ \\
\hline $\begin{array}{l}\text { N-acetyl- } \beta-D- \\
\text { hexosaminidase }\end{array}$ & $\begin{array}{l}10 \mu 1 \text { extract }+200 \mu 10.05 \mathrm{M} \\
\text { citrate } p \mathrm{H} 4.5 \text { containing } \\
0.5 \mathrm{mg} / \mathrm{ml} 4 \text {-methyl- } \\
\text { umbelliferyl-2-acetamido-2- } \\
\text { deoxy- } \beta-\mathrm{D}-\text {-glucopyranoside }\end{array}$ & 20 minutes \\
\hline$\beta$-galactosidase & $\begin{array}{l}10 \mu \mathrm{l} \text { extract }+200 \mu \mathrm{l} 0.05 \mathrm{M} \\
\text { citrate } p \mathrm{H} 4.0 \text { containing } \\
0.5 \mathrm{mg} / \mathrm{ml} \text { 4-methylumbelli- } \\
\text { feryl-B-D-galactopyranoside } \\
\text { (Koch-Light) and } 0.45 \% \\
\mathrm{NaCl}\end{array}$ & 20 minutes \\
\hline$\alpha$-arabinosidase & $\begin{array}{l}10 \mu \mathrm{l} \text { extract }+2000.1 \mathrm{M} \\
\text { citrate } p \mathrm{H} 4.5 \text { containing } 1 \\
\text { mg/ml 4-methylumbelli- } \\
\text { feryl- } \alpha \text {-L-arabinopyranoside } \\
\text { (Koch-Light) }\end{array}$ & 20 minutes \\
\hline
\end{tabular}

Assays were stopped by the addition of $0.3 \mathrm{M}$ glycine/ $\mathrm{NaOH}$ pH 10.6 to a final volume of $3 \mathrm{ml}$. The free methylumbelliferone was measured using a Perkin-Elmer fluorimeter. Excitation at $360 \mathrm{~m} \mu$ emission at $450 \mathrm{~m} \mu$.

It was soon realized that his ability to sweat was impaired and by early adolescence his ankles and legs began to swell. As he grew older the attacks of pain became less frequent and the severity of pain eased. He was first seen and diagnosed in September 1963. He was tall with long slender arms and fingers, prominent thick lips, and myopia. There was pitting oedema of both ankles extending half-way up the legs. His cardiovascular and respiratory systems were normal. Blood pressure was $130 / 80 \mathrm{mmHg}$. Skin examination showed crops of extensive, small angiokeratomata (Fig. 2) on his lower lip, thighs, flanks, buttocks, scrotum, and penis. Investigations showed a normal haemoglobin, white cell count, and platelets. LE cells were not seen. Serum cholesterol was $5.05 \mathrm{mmol} / 1$ (195 $\mathrm{mg} / 100 \mathrm{ml})$. Plasma urea was $3.5 \mathrm{mmol} / 1(21 \mathrm{mg} / 100$ $\mathrm{ml}$ ). There was proteinuria. An intravenous pyelogram was normal. A skeletal survey revealed bilateral cervical ribs, a bifid 7 th cervical vertebra, and partial fusion of C2 with C3 and C6 with C7. Electromyography and electroencephalography were normal.

Review in 1967 confirmed the presence of proteinuria but the plasma urea remained normal at $3.5 \mathrm{mmol} / 1$ $(21 \mathrm{mg} / 100 \mathrm{ml})$. Rectal wall biopsy and sternal marrow (Fig. 3) showed large lipid-laden foam cells consistent with the diagnosis of Anderson-Fabry's disease. Hydroxyproline excretion was normal.

Further review in April 1974 showed no deterioration in renal function. Proteinuria persisted but his plasma creatinine was $106 \mu \mathrm{mol} / 1(1.2 \mathrm{mg} / 100 \mathrm{ml})$ and plasma urea was $3.5 \mathrm{mmol} / 1(21 \mathrm{mg} / 100 \mathrm{ml})$. In April 1975, at the age of 45 , the patient sustained an anterior myocardial infarct.

Case IV.7 (LM D/B 21.12.1933). LM, the second brother, developed normally but unlike the other three brothers his ankle and leg pains were not particularly troublesome. When first reviewed in 1967, his physique was similar to that of his brothers, with fleshy thick lips and long slender arms. Investigations showed no proteinuria, and the plasma urea was normal. Sternal marrow and rectal wall biopsy showed typical changes of Anderson-Fabry's disease with lipid-laden foam cells. Cutaneous angiokeratomata were present on his buttocks, lower trunk, scrotum, and elbows. Pitting oedema was present around both ankles. In 1974 proteinuria was detected but plasma urea was again normal at $3 \mathrm{mmol} / 1$ (18 $\mathrm{mg} / 100 \mathrm{ml}$ ).

Case IV.8 (WM D/B 14.6.1935). WM first began to complain of aches and pains in his ankles and legs at the age of 8 . Heat intolerance and hypohidrosis soon followed and oedema of the ankles was noted by the age of 16 . In 1966 at the age of 31 he was admitted to this hospital for investigation of proteinuria. He had a normal plasma urea and a normal intravenous pyelogram. Sternal marrow and rectal wall biopsy showed changes typical of Anderson-Fabry's disease. In 1967 he developed a mild left hemiparesis but this rapidly improved.

Review in 1974 showed no neurological deficit. There was some deterioration in renal function, with a serum creatinine of $177 \mu \mathrm{mol} / 1(2.0 \mathrm{mg} / 100 \mathrm{ml})$, creatinine clearance of $42 \mathrm{ml} / \mathrm{min}$, and daily proteinuria of 2 to 3 grams.

Case IV.9 (AM D/B 17.6.1938; died 8.6.1960). $\mathrm{AM}$, the youngest member of the family, developed normally until the age of 11 when he started experiencing severe pains in his legs, feet, arms, and back of the head. By the age of 15 his pains became very severe and he was referred to this hospital where a collagen vascular disease was diagnosed on the basis of his musculoskeletal complaints, episodes of pyrexia, and associated raised erythrocyte sedimentation rate. He was the first of the brothers to be seen in this hospital but not by us. In 1954 he was started on treatment with oral cortisone acetate. This was later changed to ACTH injections and eventually prednisone was prescribed. He remained on corticosteroid therapy until his death in 1960. 


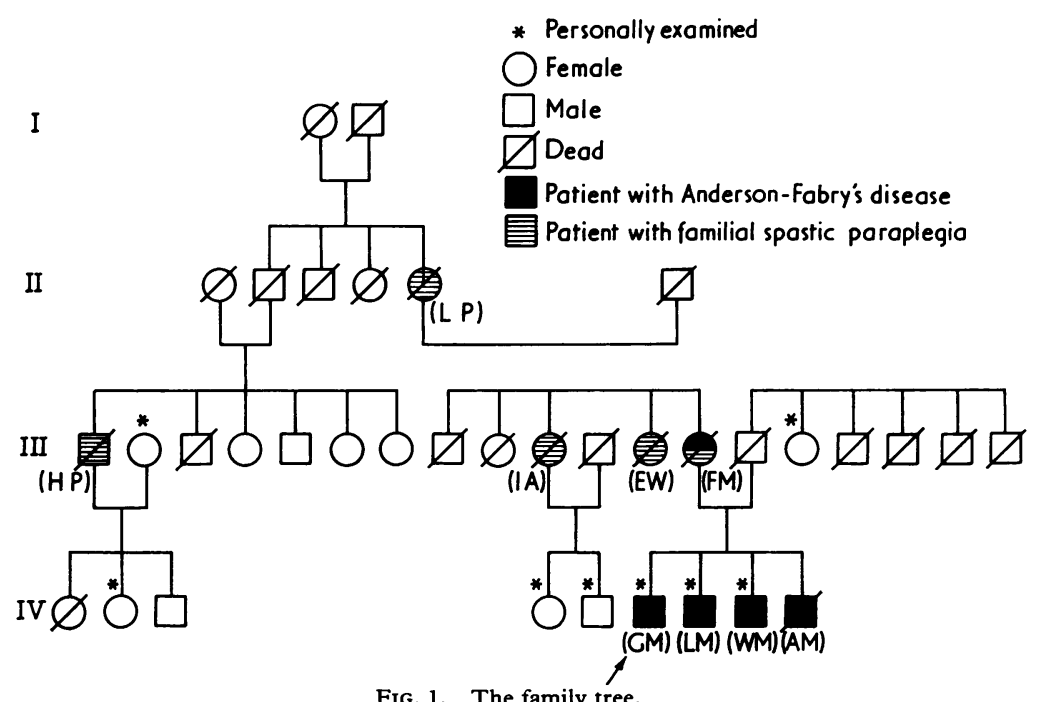

Fig. 1. The family tree.

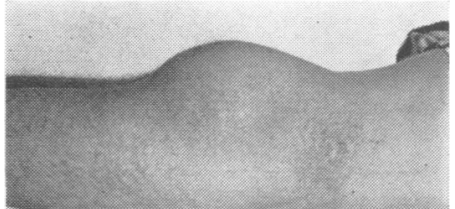

Fig. 2. Typical cutaneous angiokeratomata in (IV.6 GM).
He developed severe osteoporosis with multiple collapsed vertebrae and a gross cushingoid appearance. The correct diagnosis was not made until after his other brothers were seen at this hospital several years later. In retrospect, after re-examining the necropsy material, there is no doubt that he too had suffered from Anderson-Fabry's disease.

Case III.13 (FM). This member of the family is described as a thin, tall lady who, from an early age, complained of swollen and painful ankles and legs.

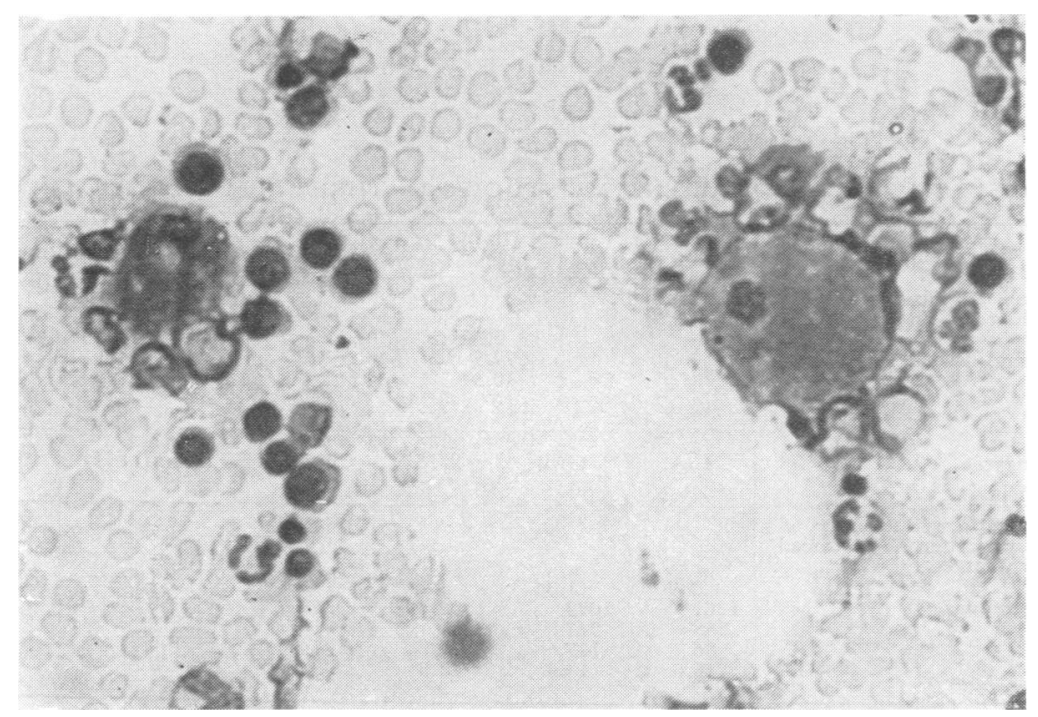

FIG. 3. (IV.6 GM) Bone-marrow smear showing large lipid-laden foam cells. 

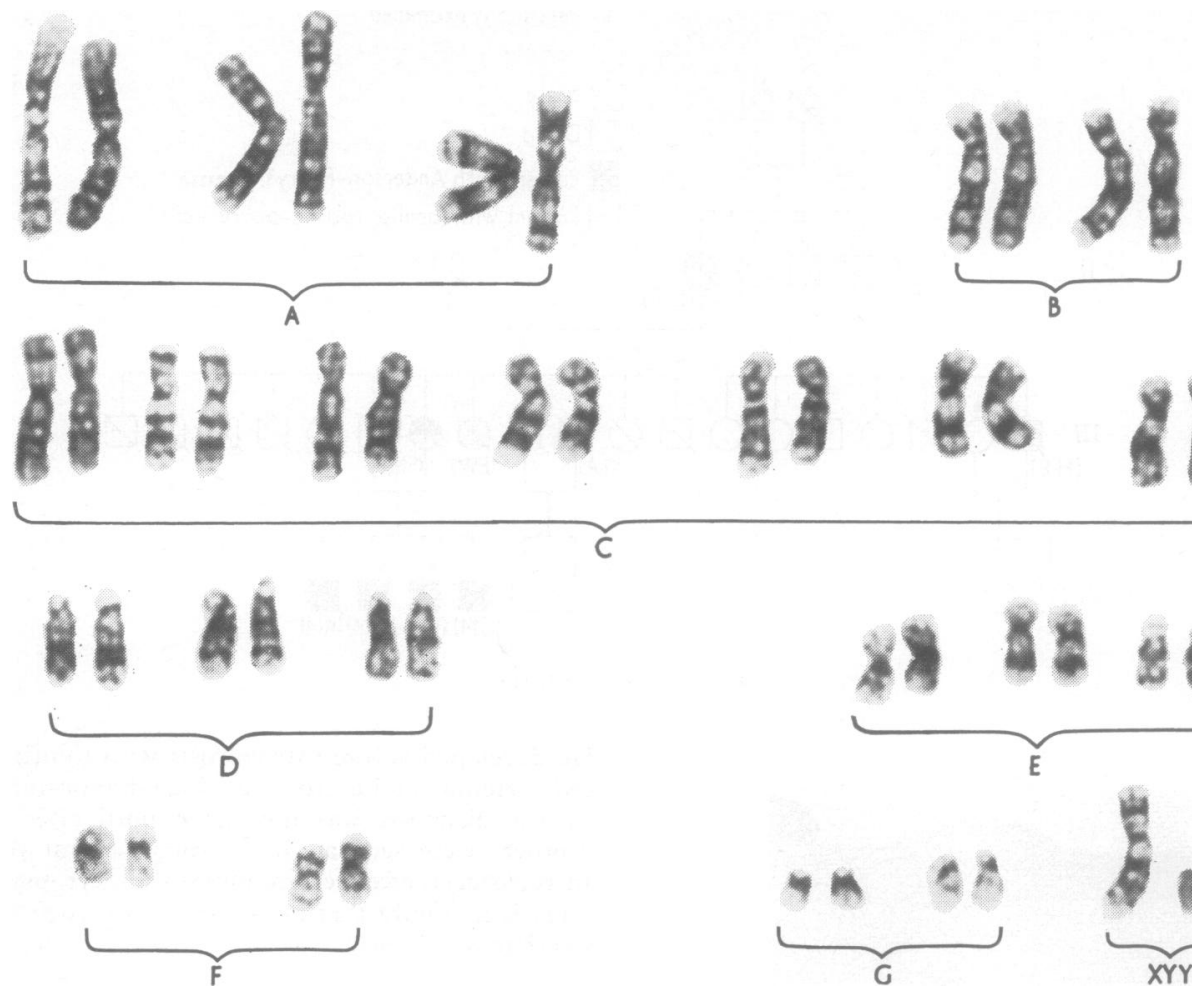

C

Fig. 4. (IV.7LM) Abnormal (47,XYY) chromosome karyotype.

TABLE II

RESULTS OF LYSOSOMAL ENZYME STUDIES IN THREE AFFECTED BROTHERS

\begin{tabular}{|c|c|c|c|c|c|c|c|c|c|c|}
\hline \multicolumn{3}{|l|}{ Enzyme } & $\mathbf{L M}$ & & GM & WM & \multicolumn{2}{|c|}{ Control Range } & \multicolumn{2}{|c|}{ No. of Controls } \\
\hline \multicolumn{3}{|c|}{$\begin{array}{l}\text { A: Plasma (results expressed in terms of n-moles 4-methyl- } \\
\text { umbelliferone produced per hour per ml plasma) } \\
\alpha \text {-galactosidase } \\
\mathrm{N} \text {-acetyl- } \beta \text {-D-hexosaminidase } \\
\alpha \text {-mannosidase }\end{array}$} & $\begin{array}{c}0.30 \\
679.5 \\
40.3\end{array}$ & & $\begin{array}{c}0.25 \\
645.9 \\
64.5\end{array}$ & $\begin{array}{c}0.20 \\
438.9 \\
54.3\end{array}$ & \multicolumn{2}{|c|}{$\begin{array}{c}3.7-7.8 \\
436-1216 \\
40-77\end{array}$} & & $\begin{array}{l}12 \\
31 \\
11\end{array}$ \\
\hline Enzyme & $\mathbf{L M}$ & GM & & WM & & ool It & Control IIt & $\begin{array}{l}\text { Cor } \\
\text { Ra }\end{array}$ & & $\begin{array}{c}\text { No. of } \\
\text { Controls }\end{array}$ \\
\hline $\begin{array}{l}\text { B: White cells (results expressed in terms of } \\
\text { n-moles } 4 \text {-methyl-umbelliferone produced } \\
\text { per hour per mg protein } * \text { ) } \\
\alpha \text {-galactosidase } \\
\mathrm{N} \text {-acetyl- } \beta-D-\text {-hexosaminidase } \\
\alpha \text {-mannosidase } \\
\beta \text {-galactosidase } \\
\alpha \text {-arabinosidase }\end{array}$ & $\begin{array}{l}1261^{1.90} \\
258 \\
86 \\
15.6\end{array}$ & $\begin{array}{l}1.36 \\
1073 \\
347 \\
127 \\
14.4\end{array}$ & & $\begin{array}{l}2.49 \\
202 \\
91 \\
10.5\end{array}$ & & $\begin{array}{l}9.55 \\
7 \\
8.4\end{array}$ & $\begin{array}{l}41.08 \\
1288 \\
319 \\
190 \\
27.3\end{array}$ & 20.0 & 41.3 & 12 \\
\hline
\end{tabular}

* Protein measured by the method of Lowry et al (1951).

+ Control samples taken on the same day as the brothers.
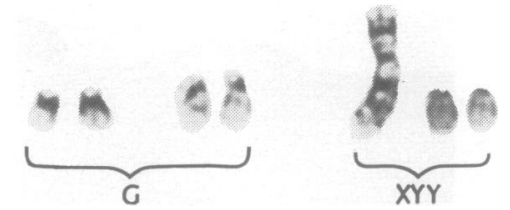


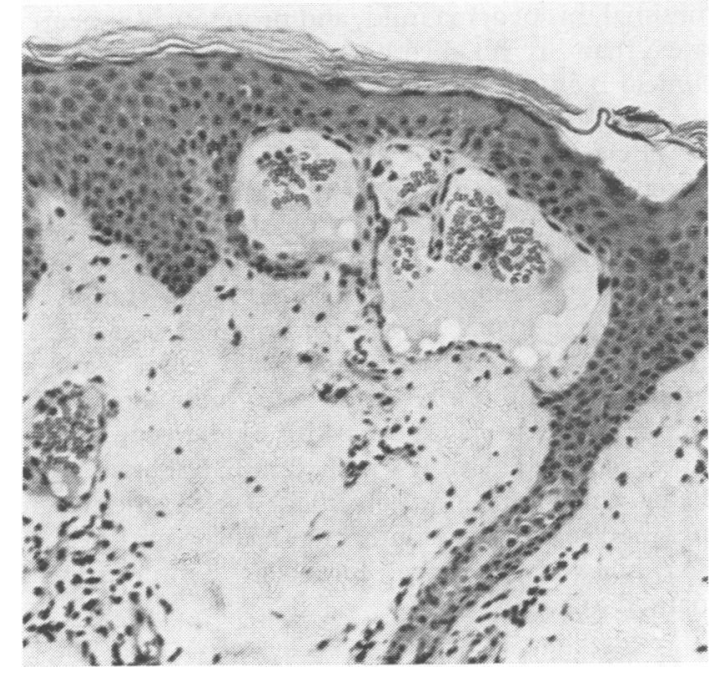

FIG. 5. Section of skin showing dilatation of subepidermal capillaries.

Cramps were particularly frequent and troublesome. Gradually these complaints became overshadowed by her incapacitating ataxia and progressive paraparesis that eventually restricted her to a wheelchair by the age of 35 .

\section{Results}

(a) Lysosomal enzymes. The results of lysosomal enzyme studies in the three surviving brothers with Anderson-Fabry's disease and controls are shown in Table II. Both the plasma and white cells of the three brothers showed a profound deficiency of total $\alpha$-galactosidase activity confirming the clinical diagnosis of Anderson-Fabry's disease. The other enzymes assayed, $\mathrm{N}$-acetyl- $\beta$-D-hexosaminidase, $\alpha$-mannosidase, $\alpha$-galactosidase and $\beta$-arabinosidase appeared to be present at normal levels.

(b) Chromosome analysis. Chromosome analysis in IV.8 WM and IV.6 GM showed normal male karyotypes $(46, \mathrm{XY})$ with no detectable deletion, translocation, or mosaicism. Surprisingly, however, IV.7 LM had an additional chromosome with karyotype 47,XYY. Results are shown in Fig. 4.

(c) Ophthalmological assessment. Ophthalmological assessment of the three surviving brothers showed typical corneal changes with wedge-shaped subepithelial deposits. Some pallisading of a superficial nature in the lower half of each cornea was also noted. No cataracts were seen and intraocular pressures were normal. Fundal examination showed large, full, and tortuous veins. No other abnormalities were noted.

(d) Histology. Histological studies on IV.8 WM confirmed dilated superficial capillaries (Fig. 5) with infiltration of the endothelium and smooth muscle by a doubly refractile glycolipid, easily demonstrable by polarized light (Fig. 6a and 6b). Histology of rectal wall confirmed similar changes with glycolipid infiltration of the smooth muscle also affecting the walls of blood vessels.

\section{Discussion}

Clinical features. During the past few years several comprehensive reviews have described the mode of development, natural history, and symptomatology of Anderson-Fabry's disease (Wise, Wallace, and Jellinek, 1962; Carton, 1972; Wallace, 1973). The affected brothers in this family exemplify most of the features of this rare disease. Painful cramps, usually the earliest presenting complaints, were present before the age of 11 in all
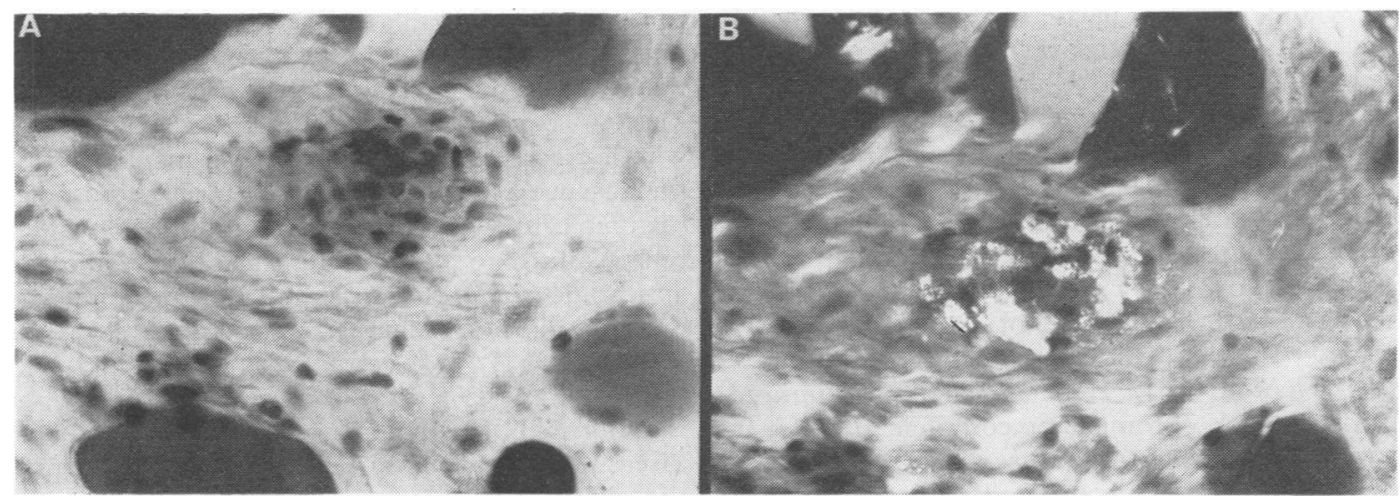

FIG. 6. Sections of skin showing refractile material within the wall of an arteriole (A, ordinary light; B, polarized light). 
brothers, and oedema of the ankles, hypohidrosis, cutaneous angiokeratomata, and proteinuria followed later. Thrombotic episodes developed in two of the patients. IV.6 GM developed a myocardial infarct at the age of 45 and IV.8 WM had a transient hemiparesis at the age of 32 . Respiratory infections are particularly common in our family. In particular IV.8 WM has asthma which is occasionally troublesome. Similar respiratory findings have been described in other families (Bagdade et al, 1968) and Fabry's original patient had asthma, frequent respiratory infections, and eventually died of his pulmonary disease. Unlike other reported families (Wise et al, 1962), the members of our family did not show any structural abnormalities of the urinary tract. Proteinuria was, however, present in all affected members. Cutaneous changes, initially the mainstay of clinical diagnosis, were found in all our patients. As previously reported in other families (Wallace, 1973) there was a variable incidence of angiokeratomata in the members of our family. IV.6 GM has extensive crops on most parts of the body (Fig. 2), while IV.8 WM had only a few crops restricted to the buttocks. Hamburger et al (1964) and Clarke et al (1971) have described patients with AndersonFabry's disease and renal involvement in the absence of cutaneous angiokeratomata. Angiokeratomata have been found in patients with storage disorders other than Anderson-Fabry's disease. The typical cutaneous changes have been seen in patients with $\beta$-galactosidase deficiency and normal $\alpha$-galactosidase levels (Loonen, Van der Lugt, and Franke, 1974; Wenger, Goodman, and Myers, 1974) and also in fucosidosis patients (Gatti et al, 1973; Kousseff et al, 1973).

Inheritance. Inheritance in Anderson-Fabry's disease is X-linked (Opitz et al, 1965) but some heterozygous female carriers demonstrate mild clinical signs, in particular early corneal dystrophic changes, which can be of diagnostic importance. In this family there is evidence to suggest that the mother (III.13 FM) had a mild form of the disease. It is unfortunate that all four brothers (Fig. 1) developed this illness. Of all families consisting of 4 brothers where the mother is a carrier, 1 in 16 is expected to show all 4 brothers affected. Chromosome abnormalities have not been previously, described in patients with Anderson-Fabry's disease. Patient IV.7 LM, appears quite unique with his $47, \mathrm{XYY}$ chromosome complement. He is also of further interest because his clinical manifestations were milder compared with those of his brothers. His musculoskeletal discomfort was minimal, his oedema mild, and proteinuria appeared later than in his brothers. Whether his milder clinical manifestations were a definite dosage effect of the Y chromosome or a chance finding can only be elicidated by the discovery of other similar patients. So far this patient has led a normal life and has had none of the psychiatric characteristics occasionally found in people with a 47,XYY chromosome complement. The whole family is even more unusual by the coincidental presence in the second and third generations of a form of familial spastic paraplegia. No member of the fourth generation shows this syndrome. Like other reported families with familial spastic paraplegia, the extent of involvement varied in different members and two members (II.5 LP and (III.13 FM) showed additional cerebellar symptoms with marked ataxia.

Management. Painful cramps are one of the most distressing features of this rare disease. Lockman et al (1973) in a double-blind crossover study, have shown the beneficial use of diphenylhydantoin in this condition. During the past few years several patients with Anderson-Fabry's disease in end-stage renal failure have received renal transplants (Desnick et al, 1972; Philippart, Franklin, and Gordon, 1972; Clarke et al, 1972; Bühler et al, 1973). Apart from the aimed benefit from improved renal function, attempts at renato transplantation were also seriously pursued because? of possible general improvement following the production by the transplanted kidney of the deficient $\alpha$-galactosidase enzyme. Desnick et al (1972) and Philippart et al (1972) were able to show a rise in plasma $\alpha$-galactosidase activity and a fall in ceramide trihexoside after successful renal transplantation. One of their patients reported return of near-normal sweating habits and relief from musculoskeletal pains. Clarke et al (1972) were not, however, able to reproduce the above good results, and in particular the sustained fall of plasma ceramide trihexoside. It is doubtful whether early prophylactic renal transplantation in the absence of end-stage renal failure is advisable or justifiable in view of the variable time it takes for renal failure to develop in this disease after the appearance of proteinuria and the morbidity and definite mortality that still accompany this procedure.

Diagnosis. The diagnosis of Anderson-Fabry's disease is easy when all features are present but in the absence of cutaneous changes or before these appear early diagnosis may be difficult. A high 
ESR and episodes of pyrexia may lead to the mistaken diagnosis of a collagen vascular disease and the administration of corticosteroids, the detrimental effects of which were clearly shown by the youngest of the four brothers who died grossly cushingoid at the age of 22 . The diagnosis can now be confirmed biochemically by measuring $\alpha$-galactosidase activity. This enzyme can be measured in plasma and white blood cells using the artificial substrate 4-methylbumbelliferyl- $\alpha$-Dgalactopyranoside, and is of particular value in suspected patients where cutaneous changes are not present. A further useful investigation is to look for corneal dystrophic changes. These are found at a very young age in patients with Anderson-Fabry's disease and are also present in carriers. The diagnosis can also be confirmed histologically by examination of sternal marrow (Fig. 3), skin (Figs. 5, 6a and 6b), rectal wall, and kidney.

Prolonged recurring cramps of ankles and legs in childhood should arouse suspicions of AndersonFabry's disease. Its early detection allows timely genetic counselling and proper management.

We would like to acknowledge the assistance of $\mathrm{Dr}$ T. J. Muckle currently of the Department of Pathology, McMaster University, Hamilton, Ontario, Canada, and Dr A. R. Morley of the Department of Pathology, Newcastle General Hospital, for their help with the histological studies in this family. We are also grateful to Mrs E. V. Wright of the Department of Human Genetics for her assistance in the chromosome studies in this family.

Dr A. M. Pierides is supported by an M.R.C. grant No. G973/693/C.

\section{REFERENCES}

Anderson, W. (1898). A case of angeio-keratoma. British fournal of Dermatology, 10, 113-117.

Bagdade, J. D., Parker, F., Ways, P. O., Morgan, T. E., Lagunoff, D., and Eidelman, S. (1968). Fabry's disease. A correlative clinical, morphologic and biochemical study. Laboratory Investigation, 18, 681-688.

Brady, R. O., Gal, A. E., Bradley, R. M., Martensson, E., Warshaw, A. L., and Laster, L. (1967). Enzymatic defect in Fabry's disease. New England fournal of Medicine, 276, 1163-1167.

Bühler, F. R., Thiel, G., Dubach, U. C., Enderlin, F., Gloor, F., and Tholen, H. (1973). Kidney transplanatation in Fabry's disease. British Medical fournal, 3, 28-29.
Carton, D. (1972). Fabry's disease: general clinical aspects, Archives Belges de Dermatologie et de Syphiligraphie, T. XXVIII. fasc. 3, p. 239-243.

Clarke, J. T. R., Guttman, R. D., Wolfe, L. S., Beaudoin, J. G., and Morehouse, D. D. (1972). Enzyme replacement therapy by renal allotransplantation in Fabry's disease. New England Fournal of Medicine, 287, 1215-1218.

Clarke, J. T. R., Knaack, J., Crawhall, J. C., and Wolfe, L. S. (1971). Ceramide trihexosidosis (Fabry's disease) without skin lesions. New England fournal of Medicine, 284, 233-235.

Desnick, J. R., Simmons, R. L., Allen, K. Y., Woods, J. E., Anderson, C. F., Najarian, J. S., and Krivit, W. (1972). Correction of enzymatic deficiencies by renal transplantation: Fabry's disease. Surgery, 72, 203-211.

Fabry, J. (1898). Ein Beitrag zur Kenntnis der Purpura haemorrhagica nodularis (Purpura papulosa haemorrhagica Hebrae). Archives of Dermatology and Syphilology, 43, 187-200.

Gatti, R., Borrone, C., Trias, X., and Durand, P. (1973). Genetic heterogeneity in fucosidosis. Lancet, $2,1204$.

Hamburger, J., Dormont, J., De Montera, H., and Hinglais, N. (1964). Sur une singulière malformation familiale de l'epithelium. Schweizerische medizinische Wochenschrift, 94, 871-876.

Jensen, E. (1966). On the pathology of angiokeratoma corporis diffusum (Fabry). Acta Pathologica et Microbiologica Scandinavica, 68, 313-331.

Kint, J. A. (1970). Fabry's disease: alpha-galactosidase deficiency. Science, 167, 1268-1269.

Kousseff, B. G., Beratis, N. G., Danesino, C., and Hirschhorn, K. (1973). Genetic heterogeneity in fucosidosis. Lancet, 2, 13871388.

Lockman, L. A., Hunninghake, D. B., Krivit, W., and Desnick, R. J. (1973). Relief of pain of Fabry's disease by diphenylhydantoin. Neurology, 23, 871-875.

Loonen, M. C. B., Van der Lugt, L., and Franke, C. I. (1974). Angiokeratoma corporis diffusum and lysosomal enzyme deficiency. Lancet, 2, 785.

Lowry, O. H., Rosenbrough, N. J., Farr, A. L., and Randall, R. J. (1951). Protein measurement with the Folin phenol reagent. fournal of Biological Chemistry, 193, 265-275.

Opitz, J. M., Stiles, F. C., Wise, D., Race, R. R., Sanger, R., von Gemmingen, G. R., Kierland, R. R., Cross, E. G., and de Groot, W. P. (1965). The genetics of angiokeratoma corporis diffusum (Fabry's disease) and its linkage relations with the $\mathrm{Xg}$ locus. American fournal of Human Genetics, 17, 325-342.

Philippart, M., Franklin, S. S., and Gordon, A. (1972). Reversal of an Inborn Sphingolipidosis (Fabry's disease) by kidney transplantation. Annals of Internal Medicine, 77, 195-200.

Scriba, K. (1950). Zur Pathogenese des Angiokeratoma corporis diffusum Fabry mit cardio-vaserenalem Symptomenkomplex. Verhandlungen der Deutschen Gesellschaft für Pathologie, 34, 221226.

Sweeley, C. C. and Klionsky, B. (1963). Fabry's disease: classification as a sphingolipidosis and partial characterization of a novel glycolipid. fournal of Biological Chemistry, 238, 31483150 .

Wallace, H. J. (1973). Anderson-Fabry disease. British fournal of Dermatology, 88, 1-23.

Wenger, D. A., Goodman, S. I., and Myers, G. G. (1974). Betagalactosidase deficiency in young adults. Lancet, 2, 1319-1320.

Wise, D., Wallace, H. J., and Jellinek, E. H. (1962). Angiokeratoma corporis diffusum. A clinical study of eight affected families. Quarterly fournal of Medicine, 31, 177-206. 